\title{
Distribución de los Nervios Cutáneo Dorsal Medial y Cutáneo Dorsal Intermedio en el Hombre
}

\author{
Distribution of the Medial Dorsal Cutaneous and Intermediate Dorsal Cutaneous Nerves in Man
}

\author{
"Karina Hunter \& ** Mariano del Sol
}

HUNTER, K. \& DEL SOL, M. Distribución de los nervios cutáneo dorsal medial y cutáneo dorsal intermedio en el Hombre. Int. J. Morphol., 28(3):891-894, 2010.

RESUMEN: Gran parte de la inervación sensitiva del dorso del pie está dada por los ramos cutáneos del nervio fibular superficial, los nervios cutáneo dorsal medial (NCDM) y cutáneo dorsal intermedio (NCDI). El objetivo de esta investigación fue estudiar las divisiones de los NCDM y NCDI a nivel del tercio distal de la pierna y el dorso del pie, para contribuir con conocimientos específicos al abordaje quirúrgico de la región. Disecamos 19 piernas y pies en cadáveres de individuos adultos, masculinos, correspondientes al Departamento de Morfología de la Universidad de La Frontera de Temuco. Se dividió el dorso del pie, en tercios anterior, medio, posterior y luego, las divisiones observadas se padronizaron. La división de los NCDM y NCDI, en ramos medial y lateral, se observó en el tercio distal de la pierna, en un 47,4\% y 52,6\% respectivamente. La división del ramo medial de los NCDM y NCDI en ramos terminales, se observó en el tercio posterior del dorso del pie $(42,2 \%)$ y en el tercio distal de la pierna $(21,1 \%)$, respectivamente. La división del ramo lateral de los NCDM y NCDI en ramos terminales, se observó en el tercio posterior del dorso del pie $(21,1 \%)$ y en el tercio anterior del dorso del pie $(15,8 \%)$ respectivamente. La división de los ramos terminales del ramo medial de los NCDM y NCDI en nervios digitales dorsales, se observó en el tercio medio del dorso del pie en un 21,1\% y 15,6\% respectivamente. La división de los ramos terminales del ramo lateral de los NCDM y NCDI en nervios digitales dorsales, se observó en el tercio anterior del dorso del pie en un 15,8\%, para ambos. Estos datos, pueden servir de referencia durante los procedimientos quirúrgicos realizados en la región, evitando lesiones iatrogénicas del área.

PALABRAS CLAVE: Nervio cutáneo dorsal medial; Nervio cutáneo dorsal intermedio; Distribución.

\section{INTRODUCCIÓN}

La inervación cutánea del dorso del pie, está dada, principalmente, por los nervios cutáneo dorsal medial (NCDM) y cutáneo dorsal intermedio (NCDI), ramos del nervio fibular superficial, y mencionada tanto en los textos de anatomía como en artículos científicos. Sin embargo, no existe una descripción detallada de la distribución y topografía de los ramos del nervio fibular superficial, ni tampoco de otros nervios, como el sural y el ramo cutáneo del nervio fibular profundo (Testut \& Jacob, 1979; Williams et al., 1995; Rouvière \& Delmas, 1999; Latarjet \& Ruiz-Liard, 2004). Otros autores, realizaron una descripción acabada de la emergencia del nervio fibular superficial y de los ramos de éste: nervio cutáneo dorsal medial y nervio cutáneo dorsal intermedio, además de los ramos comunicantes del nervio fibular superficial con el nervio sural y la zona de inervación terminal (Gabrielli et al., 2005).
Igualmente, Solomon et al., 2001; Madhavi et al., 2005 y Wahee et al., 2010; efectuaron el estudio de la distribución del nervio fibular superficial en la pierna y dorso del pie, en distintos grupos etáreos. Sin embargo, estos mismos autores no efectuaron un estudio sistemático y detallado de las divisiones de los ramos del nervio fibular superficial en el dorso del pie.

En la literatura, en general, existe escasa información anatómica, detallada de la distribución de los NCDM y NCDI en el Hombre. Lo anterior, nos motivó a estudiar sus divisiones en el tercio distal de la pierna y en el dorso del pie, para de esta manera, contribuir al conocimiento anatómico de las regiones anteriormente señaladas y a las técnicas quirúrgicas actuales.

\footnotetext{
* Universidad Autónoma de Chile, Sede Temuco, Chile. Programa de Magíster en Ciencias, Mención Morfología, Universidad de La Frontera, Chile.

** Facultad de Medicina, Universidad de La Frontera, Chile.

Financiado por Proyecto DIUFRO No 120411, Universidad de La Frontera, Chile.
} 


\section{MATERIAL Y MÉTODO}

Se efectuaron disecciones en 19 piernas y pies, de cadáveres adultos, de sexo masculino, provenientes de la Facultad de Medicina de la Universidad de La Frontera, Temuco, Chile. Para la disección mesoscópica, se utilizó el protocolo de disección de del Sol \& Prates (1988), además de material quirúrgico ad hoc, una lupa marca Ransor (5 X) y una cinta métrica Rosscraft ${ }^{\circledR}$. Se utilizaron como puntos de referencia óseos, el cóndilo medial de la tibia, para realizar la medición de la longitud de la pierna y su división en tercios; línea intermaleolar y articulaciones metatarsofalángicas del primer a quinto dedos, para establecer los sitios a lo largo de los NCDM y NCDI, donde éstos se dividieron, y así, permitir la identificación correcta a nivel de los tercios anterior, medio o posterior del dorso del pie. Hacemos notar que se describieron todos aquellos nervios, que poseían un grosor superior a $0,2 \mathrm{~mm}$, con un caliper electrónico digital, Mitutoyo ${ }^{\circledR}$, de precisión $0,01 \mathrm{~mm}$. y que eran visibles y disecables bajo la lupa. Finalmente, las muestras fueron fotografiadas y esquematizadas.

\section{RESULTADOS}

$\mathrm{Al}$ alcanzar el dorso del pie la mayoría de los NCDM y NCDI, se dividen en ramos mediales y laterales, hasta llegar a constituir los ramos terminales o nervios digitales dorsales del pie. Para la localización topográfica del sitio de división de estos nervios, la longitud del dorso del pie fue dividida en tercios, los que fueron denominados anterior, medio y posterior. Cada uno de ellos, se subdividió en partes anterior, media y posterior. Se padronizaron las divisiones observadas en los NCDM, NCDI:

- División del NCDM y NCDI, corresponde a los ramos medial y lateral del NCDM/ NCDI.

- Primera división del ramo medial/lateral del NCDM/ NCDI, corresponde a la división del ramo medial y lateral del NCDM / NCDI en ramos terminales del ramo medial/ lateral del NCDM/NCDI. - Segunda división del ramo medial/lateral del NCDM/ NCDI, corresponde a la división de los ramos terminales del ramo medial/ lateral del NCDM/NCDI en nervios digitales dorsales del NCDM/NCDI.

División del NCDM: Se dividió en ramos medial y lateral. En 9 casos $(47,4 \%)$ se ubicó en el tercio distal de la pierna; en 3 casos $(15,8 \%)$ en el tercio posterior del dorso del pie parte posterior; en 4 casos $(21,1 \%)$ en el tercio posterior del dorso del pie parte media, y en 2 casos (10,5\%) en el tercio posterior del dorso del pie parte anterior. En 1 de los casos $(5,2 \%)$ el NCDM no presentó división.
División del ramo medial del NCDM: Se dividió en ramos terminales. En 2 casos (10,5\%) se ubicó en el tercio posterior del dorso del pie parte posterior; en 4 casos $(21,1 \%)$ en el tercio posterior del dorso del pie parte media; en 4 casos $(21,1 \%)$ en el tercio posterior del dorso del pie parte anterior; en 1 caso $(5,2 \%)$ en el tercio medio del dorso del pie parte posterior, y en 1 caso $(5,2 \%)$ en el tercio medio del dorso del pie parte anterior. En 7 casos $(36,9 \%)$ el ramo medial del NCDM no presentó división.

División del ramo lateral del NCDM: Se dividió en ramos terminales. En 1 caso $(5,2 \%)$ se ubicó en el tercio posterior del dorso del pie parte posterior; en 1 caso $(5,2 \%)$ en el tercio posterior del dorso del pie parte media; en 4 casos $(21,1 \%)$ en el tercio posterior del dorso del pie parte anterior, en 1 caso $(5,2 \%)$ en el tercio medio del dorso del pie parte posterior; en 2 casos $(10,5 \%)$ en el tercio medio del dorso del pie parte media, y en 2 casos $(10,5 \%)$ en el tercio medio del dorso del pie parte anterior. En 8 casos $(42,3 \%)$ el ramo lateral del NCDM no presentó división.

Ramos terminales del ramo medial del NCDM: Se dividió en nervios digitales dorsales. En 2 casos (10,5\%) se ubicó en el tercio posterior del dorso del pie parte anterior; en 1 caso $(5,2 \%)$ en el tercio medio del dorso del pie parte media; en 4 casos $(21,1 \%)$ en el tercio medio del dorso del pie parte anterior; en 1 caso $(5,2 \%)$ en el tercio anterior del dorso del pie parte posterior; en 1 caso $(5,2 \%)$ en el tercio anterior del dorso del pie parte media, y en 1 caso $(5,2 \%)$ en el tercio anterior del dorso del pie parte anterior. En 9 casos $(47,6 \%)$ el ramo terminal del ramo medial del NCDM no presentó división.

Ramos terminales del ramo lateral del NCDM: Se dividió en nervios digitales dorsales. En 3 casos $(15,8 \%)$ se ubicó en el tercio medio del dorso del pie parte posterior, y en 3 casos $(15,8 \%)$ en el tercio anterior del dorso del pie parte posterior. En 13 casos $(68,4 \%)$ el ramo terminal del ramo lateral del NCDM no presentó división.

División del NCDI: Se dividió en ramos medial y lateral. En 10 casos $(52,8 \%)$ se ubicó en el tercio distal de la pierna; en 3 casos $(15,8 \%)$ en el tercio posterior del dorso del pie parte anterior; en 2 casos $(10,5 \%)$ en el tercio medio del dorso del pie parte media; en 2 casos (10,5\%) en el tercio anterior del dorso del pie parte posterior, y en 1 caso $(5,2 \%)$ en el tercio anterior del dorso del pie parte media. En 1 caso $(5,2 \%)$ el NCDI no presentó división.

División del ramo medial del NCDI: Se dividió en ramos terminales. En 4 casos $(21,1 \%)$ se ubicó en el tercio distal de la pierna, y en 3 casos $(15,8 \%)$ en el tercio medio del dorso del pie parte anterior. En 12 casos $(63,1 \%)$ el ramo medial del NCDI no presentó división. 
División del ramo lateral del NCDI: Se dividió en ramos terminales. En 1 caso $(5,2 \%)$ se ubicó en el tercio posterior del dorso del pie parte anterior; en 1 caso $(5,2 \%)$ en el tercio medio del dorso pie parte posterior; en 2 casos (10,5\%) en el tercio medio del dorso del pie parte media; en 2 casos $(10,5 \%)$ en el tercio medio del dorso del pie parte anterior, y en 3 casos $(15,8 \%)$ en el tercio anterior del dorso del pie parte posterior. En 10 casos $(52,8 \%)$ el ramo lateral del NCDI no presentó división.

Ramos terminales del ramo medial del NCDI: Se dividió en nervios digitales dorsales. En 1 caso $(5,2 \%)$ se ubicó en el tercio medio del dorso del pie parte posterior; en 1 caso $(5,2 \%)$ en el tercio medio del dorso del pie parte media, y en 1 caso $(5,2 \%)$ en el tercio medio del dorso del pie parte anterior. En 16 casos $(84,4 \%)$ el ramo terminal del ramo medial del NCDI no presentó división. (Fig. 1.)

Ramos terminales del ramo lateral del NCDI: Se dividió en nervios digitales dorsales. En 1 caso $(5,2 \%)$ se ubicó en el tercio medio del dorso del pie parte anterior; en 1 caso $(5,2 \%)$ en el tercio anterior del dorso del pie parte posterior, y en 2 casos (10,5\%) en el tercio anterior del dorso del pie parte anterior. En 15 casos $(79,1 \%)$ el ramo terminal del ramo lateral del NCDI no presentó división.

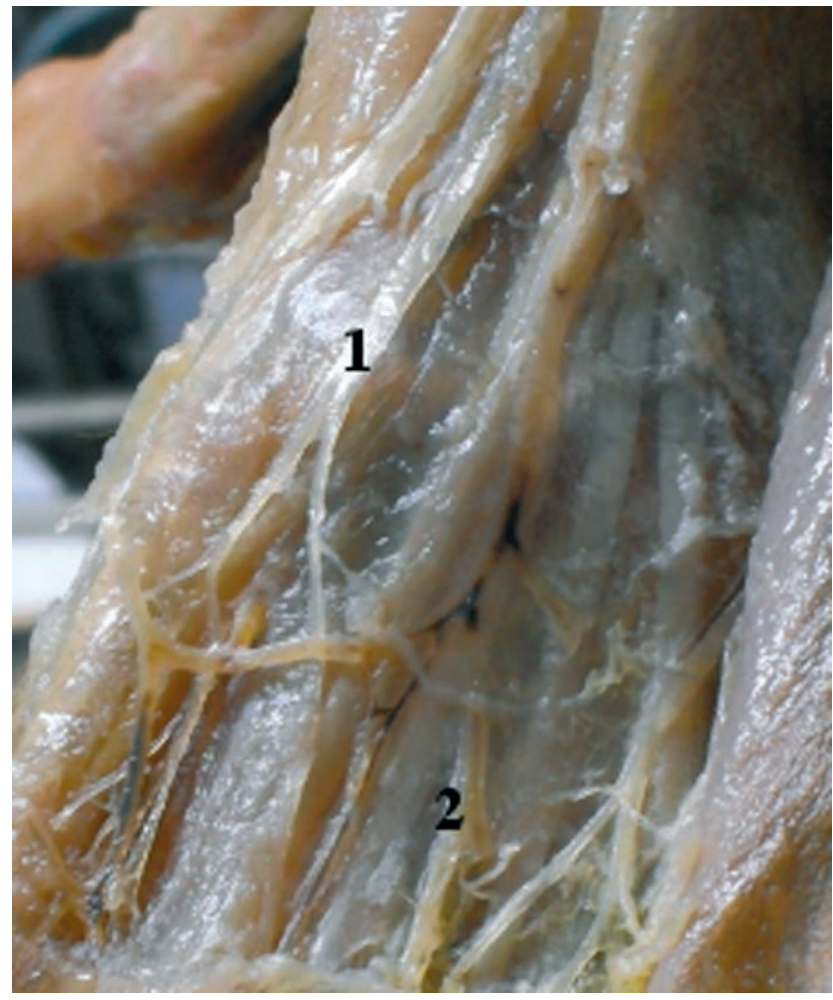

Fig. 1. Pie izquierdo de individuo adulto de sexo masculino. Región dorsal del pie. 1. Ramo del nervio cutáneo dorsal medial; 2. Segunda división del ramo medial del nervio cutáneo dorsal intermedio.

\section{DISCUSIÓN}

La microanatomía ha contribuido a significantes avances en la microcirugía reconstructiva, permitiendo perfeccionar los resultados del tratamiento quirúrgico y de las lesiones nerviosas en la región del miembro inferior. (Büyükmumcu et al., 1999; Shin et al., 2001; Yang et al., 2006). Así, variaciones encontradas en la distribución topográfica de los ramos del NCDM y NCDI, podrían cobrar importancia, cuando uno de estos ramos sean utilizados como injerto autógeno.

En la literatura consultada no existen antecedentes sobre el lugar de división en el dorso del pie para los NCDM y NCDI. Sin embargo, nos pareció interesante realizar la descripción donde ocurren estas divisiones. Hay que hacer notar, que ambos nervios presentaban una división medial y lateral y ramos terminales. Todos estos ramos no se encuentran descritos en la Terminología Anatómica (2001) y nos hemos permitido designarlos con estos nombres debido a la localización topográfica que cada uno de ellos presentó en relación a la posición anatómica.

Adkinson et al., 1991; Blair \& Botte, 1994; Canovas et al., 1996; Takao et al., 1998; Solomon et al.; Gabrielli et al.; Madhavi et al.; Barret et al., 2006; Kurtoglu et al., 2006; Yang et al.; Wahee et al. y el Comité Internacional de Terminología Anatómica, sólo identificaron la primera división y los ramos terminales o nervios digitales dorsales de los NCDM y NCDI. Por lo cual, no se clarifica respecto al número de divisiones previas a los nervios digitales dorsales del pie, si observados en la disección de nuestro estudio.

Es importante señalar, que al existir numerosas variaciones en la distribución de los ramos del NCDM y NCDI, dificulta la padronización de normalidad de la inervación cutánea en el dorso del pie. Avalado en las diferentes investigaciones realizadas por Kosinski, 1926; Adkinson et al.; Blair \& Botte; Takao et al.; Solomon et al.; Gabrielli et al.; Madhavi et al.; Barret et al. y Wahee et al.

Las descripciones topográficas y posibles variaciones anatómicas de los NCDM, NCDI en el dorso del pie resultan de vital importancia en la clínica y en la cirugía actual, donde es necesario aislar y proteger a los diversos ramos. Sería interesante aumentar el número de las muestras disecadas para un futuro estudio, y así poder establecer patrones de normalidad en la distribución sensitiva de la región dorsal del pie, donde se encuentran estos nervios. 
HUNTER, K. \& DEL SOL, M. Distibution of the medial dorsal cutaneous and intermediate dorsal cutaneous nerves in man. Int. J. Morphol., 28(3):891-894, 2010.

SUMMARY:The sensory innervation of the dorsum of the foot is given by the cutaneous branches of the superficial fibular nerve, the medial dorsal cutaneous (MDCn) and intermediate dorsal cutaneous (IDCn) nerves. The aim of this research was to study the divisions of the MDCn and IDCn at the distal third of the leg and dorsum of the foot, to contribute expertise for the surgical approach in the región. Nineteen legs and feet of adult male cadavers, of the Department of Morphology, Universidad de La Frontera in Temuco, were dissected. We divided the dorsum of the foot in anterior, middle and posterior third, then the divisions were observed and patterned. The division of the MDCn and IDCn in medial and lateral branches was observed in the distal third of the leg, $47.4 \%$ and $52.6 \%$ respectively. The division of the medial branch of the MDCn and IDCn in terminal branches, was observed in the posterior third of the dorsum of the foot $(42.2 \%)$ and in the distal third of the leg $(21.1 \%)$, respectively. The division of the lateral branch of the MDCn and IDCn in terminal branches, was observed in the posterior third of the dorsum of the foot (21.1\%) and in the anterior third of the dorsum of the foot $(15.8 \%)$ respectively. The division of the terminal branches of the medial branch of the MDCn and IDCn in dorsal digital nerves was observed in the middle third of the dorsum of the foot at $21.1 \%$ and $15.6 \%$ respectively. The division of the terminal branches of the lateral branch of the MDCn and IDCn in dorsal digital nerves was observed in the anterior third of the dorsum of the foot at $15.8 \%$ for both. These data may serve as a reference during surgical procedures performed in the region, avoiding iatrogenic injuries of the area.

KEY WORDS: Medial dorsal cutaneous nerve; Intermediate dorsal cutaneous nerve; Distribution.

\section{REFERENCIAS BIBLIOGRÁFICAS}

Adkinson, D. P.; Bosse, M. J.; Gaccione, D. R. \& Gabriel, K. R. Anatomical variations in the course of the superficial peroneal nerve. Am. J. Bone. Joint. Surg., 73:112-4, 1991.

Barret, S.; Lee Dellon, A.; Rosson, G. \& Walters, L. Superficial peroneal nerve (superficial fibularis nerve). The clinical implications of anatomic variability. J. Foot \& Ankle Surgery, 45(3):174-6, 2006.

Blair, J. \& Botte, M. Surgical anatomy of the superficial peroneal nerve in the ankle and foot. Clin. Orthop., 305:229-38, 1994.

Büyükmumcu, M.; Üstün, M. E.; Seker, M.; Kocaogullari, Y. \& Sagmanligil, A. The possibility of deep peroneal nerve neurotisation by the superficial peroneal nerve: an anatomical approach. J. Anat., 194:309-12, 1999.

Canovas, F.; Bonnel, F. \& Kouloumdjian, P. The superficial peroneal nerve at the foot. Organisation, surgical applications. Surg. Radiol. Anat., 18(3):241-4, 1996.

Comité Internacional de Terminología Anatómica. Terminología Anatómica: terminología anatómica internacional. Madrid, Panamericana, 2001.

Gabrielli, C.; Froehner, I. J. \& Braga, M. T. T. Anatomical and biometric aspects of the cutaneous distribution of the superficial fibular nerve. Int. J. Morphol., 23(2):163-70, 2005.

Kosinski, C. The course mutual relations and distribution of the cutaneous nerves of the metazonal region of leg and foot. $J$. Anat., 60(3): 274-97, 1926.

Kurtoglu, Z.; Aktekin, M. \& Haluk, M. Branching patterns of the common and supeficial fibular nerves in fetus. Clin. Anat., 19:621-6, 2006.

Latarjet, M. \& Ruiz-Liard, A. Anatomía Humana. 4ª Ed. Buenos Aires, Panamericana, 2004. V. 1.
Madhavi, C.; Isaac, B.; Antoniswamy, B. \& Holla, S. J. Anatomical variations of the cutaneous innervation patterns of the sural nerve on the dorsum of the foot. Clin. Anat., 18:206-9, 2005.

Rouvière, H. \& Delmas, A. Anatomía Humana. 10ª Ed. Barcelona, Masson, 1999.

Shin, J.; Mehmet, D.; Badr, D.; Aluisio, C. \& Gwen, C. Distal sensory nerve conduction of the superficial peroneal nerve: new method and its clinical application. Muscle Nerve, 24:68994, 2001.

Solomon, L.; Ferris, L.; Tedman, R. \& Henneberg, M. Surgical anatomy of the sural and superficial nerves with an emphasis on the approach to the lateral malleolus. J. Anat., 199:717-23, 2001.

Takao, M.; Uchio, Y.; Shu, N. \& Ochi, M. Anatomic bases of ankle arthroscopy: study of superficial and deep peroneal nerves around anterolateral and anterocentral approach. Surg. Radiol. Anat., 20(5):317-20, 1998.

Testut, L. \& Jacob, O. Compendio de Anatomía Topográfica. 11 Ed. Barcelona, Salvat, 1979.

Wahee, P.; Aggarwal, A.; Harjeet. \& Sahni, D. Variable patterns of cutaneous innervation on the dorsum of foot in fetuses. Surg. Radiol. Anat., 2010. In press. DOI 10.1007/s00276-009-0587-7.

Williams, P.; Warwick, R.; Dyson, M. \& Bannister, L. Gray Anatomía. $37^{a}$ Ed. Rio de Janeiro, Guanabara Koogan, 1995. V. 1.

Yang, L.; Gala, V. \& McGillicuddy, J. Superficial peroneal nerve síndrome: an unusual nerve entrapment. J. Neurosurg., 104:820-823, 2006.

Dirección para correspondencia:

Karina Hunter

Universidad Autónoma de Chile

Sede Temuco - CHILE

Email: karihunter78@gmail.com

Aceptado: 04-07-2010 